\title{
Comments on Dietary Restriction, Okinawa Diet and Longevity
}

\author{
Natalia S. Gavrilova Leonid A. Gavrilov \\ Center on Aging, NORC and the University of Chicago, Chicago, III., USA
}

\author{
Key Words \\ Dietary restriction $\cdot$ Longevity $\cdot$ Okinawa $\cdot$ Infections \\ Centenarians
}

\begin{abstract}
Longevity in Okinawa is considered to be a result of traditional low calorie diet. Le Bourg suggests that Okinawa is an example of severe malnutrition, which is harmful for later generations. We believe that current loss of longevity advantage in Okinawa is a result of diet westernization and that the dietary restriction is a valid way of life extension in humans.
\end{abstract}

Copyright $\odot 2011$ S. Karger AG, Basel

In a recent issue of this journal, Le Bourg questions the usefulness of dietary restriction (DR) as a means of life extension for humans and suggests that Okinawa is an example of severe malnutrition of mothers having devastating effects on younger generations [1]. Indeed, younger generations of Okinawans are losing their longevity advantage. We believe, however, that the most likely cause of this process is westernization of diet in Okinawa rather than low caloric consumption of parents. Studies of nonobese humans demonstrate an improved cardiovascular profile as a result of DR, although DR may increase susceptibility to infections. A relatively low infectious load combined with low calorie consumption in the past seems to be responsible for exceptional longevity in Okinawa. Although severe caloric restriction seems not to be a necessary condition for life extension in humans, DR should not be dismissed as a valid way of delaying atherosclerosis and eventually extending the life span of nonobese individuals.

A more careful look at the existing literature leads us to the conclusion that it is too early to give up the idea of human life extension by DR because the results of the most critical human trials on DR are in progress now and their results are yet to be published [2].

People of the Okinawa archipelago in Japan whose traditional diet is low in calories but nutritionally dense were shown to have one of the highest longevity rates in the world [3]. For example, in 2005 life expectancy at age 65 for Okinawa women was 24.86 years compared to 23.42 for Japanese women (who already had the highest life expectancy among industrialized countries). For men in 2005, life expectancy at age 65 was 19.16 versus 18.33 in Japan [4]. These data show about $5 \%$ longevity advantage for 65 -year-old women and about $4 \%$ longevity advantage for 65-year-old men in Okinawa compared to Japan. In 2000 , life expectancy at age 65 in Okinawa was 24.1 years for women and 18.5 years for men that demonstrates a continuous increase (rather than decrease) in longevity in Okinawa. A study of older Okinawans demonstrated that they appear to have undergone a mild form of prolonged

\section{KARGER}

Fax +4161306 1234

E-Mail karger@karger.ch

www.karger.com
(C) 2011 S. Karger AG, Basel

0304-324X/12/0583-0221\$38.00/0

Accessible online at:

www.karger.com/ger
Natalia S. Gavrilova, $\mathrm{PhD}$

Center on Aging

NORC and the University of Chicago

1155 E 60th Street, Chicago, IL 60637 (USA)

Tel. +1 773702 1375, E-Mail gavrilova@ longevity-science.org 
DR for about half their adult lives [5]. It was also shown that the composition of a traditional Okinawan diet is similar to a Mediterranean diet and a DASH (Dietary Approaches to Stop Hypertension) diet, which are known to be beneficial to human health later in life $[3,5]$. Indeed, Okinawans have low mortality from aging-related diseases later in life [3].

It should be noted that this longevity advantage in Okinawa is observed only for generations born before World War II. Younger generations of Okinawans are losing their longevity advantage compared to mainland Japanese. Moreover, life expectancy at birth for men in Okinawa is now lower than the country average: 78.64 years in Okinawa compared to 78.79 years in Japan in 2005 [4]. Le Bourg tries to blame the traditional low-calorie Okinawan diet on these negative changes in life expectancy. He believes that low protein intake in the past, which may result in delayed menarche and deficient lactation of mothers, resulted in poor health of both mothers and their children and eventually caused the decreasing longevity advantage in Okinawa. However, delayed age at menarche and poor lactation are rather indicators of impaired reproduction and do not necessarily result in higher mortality at older ages. In addition, it is early rather than late age of menarche which is associated with a higher mortality later in life [6]. Low birth weight is another cause of decreasing longevity advantage in Okinawa according to Le Bourg. Although low birth weight was found to be associated with diseases later in life, these effects were not particularly strong $[7,8]$. More recent data show that low birth weight increases the risk of chronic diseases later in life only if it is accompanied by subsequent rapid catch-up growth $[9,10]$. Such a scenario was unlikely for Okinawans in the past. If low birth weight is so bad for health later in life, then it is not clear why Okinawans (who have probably always had a lower birth weight compared to the mainland Japanese) managed to have low mortality from old-age diseases compared to countries with higher birth weights. Moreover, studies of severe malnutrition during a famine period (e.g. Dutch famine, Leningrad siege) found only small effects of mothers' starvation on late-life health of babies conceived during the famine $[11,12]$. In addition, the proportion of infants with low birth weight in Okinawa (7-11\%) [13] is not high enough to result in any substantial changes in adult mortality given the rather modest effects of low birth weight on late-life health.

Westernization of diet in Okinawa seems to be a more plausible and simple explanation of the observed loss of longevity advantage by younger generations of Okina- wans. Okinawa now hosts more than a dozen of Kentucky Fried Chicken restaurants and other fast food places. After World War II, BMI and energy intake of Okinawans were gradually increasing while energy expenditure was decreasing so that between the 1960s and 1970s adult Okinawans ceased to be in a caloric restriction state [3]. This process was accompanied by a spread of cardiovascular diseases. Similar processes were well described in epidemiological studies of Japanese migrants to America [14]. Current demographic and nutritional data suggest that the remarkable Okinawan longevity is now a phenomenon of the past.

It would be inaccurate to say that there are no studies of DR in normal-weight humans. There are at least two projects on DR in humans that deserve attention. The first project examines effects of DR on cardiovascular and inflammatory biomarkers among the members of the Calorie Restriction with Optimal Nutrition (CRONies) society self-imposing DR. Members of the DR group showed decreased inflammatory mediators [15] and a more favorable cardiovascular profile [16] compared to people practicing traditional westernized diet. Recently, the US National Institute on Aging initiated the CALERIE (Comprehensive Assessment of the Long-term Effects of Reducing Intake of Energy) research program which is the first systematic investigation of $25 \%$ caloric restriction in nonobese men and women aged 25-45 years [2]. Some promising results of the initial phase of this study are already published [17]. In particular, 6 months of $25 \%$ caloric restriction resulted in significant reductions in fasting insulin concentrations and body temperature, which are known biomarkers of longevity [17]. The DR group also demonstrated improved insulin sensitivity, reduced energy metabolism and reduced oxidative stress to DNA [17]. Taking into account the relatively young age of the study subjects in the CALERIE study, we should have some patience to see the results for effects of DR on human longevity. Positive changes in the cardiovascular profile as a result of DR do not mean that DR is free of side effects. Researches list several potentially adverse consequences of DR: decrease in sex hormones with subsequent bone thinning, cold sensitivity, slower wound healing, psychological changes including depression and anxiety [18].

One potential problem of low calorie consumption may be increased susceptibility to pathogens reported in animal studies [19]. It is interesting that the Okinawa archipelago apparently had a low infectious load in the past. This conclusion follows from a relatively low infant mortality in 1900 and 1940 [1]. Taking into account that an 
overwhelming majority of infant deaths before the 1930 s was caused by infections, low infant mortality may serve as a good indicator of environmental infectious load. Finch and Crimmins [20] suggest that childhood infection exposure may serve as a trigger of chronic inflammation later in life. Thus, it is reasonable to hypothesize that the unusually low mortality of older Okinawans could result from the fortunate combination of a low infectious load during childhood and low calorie consumption during the life course. Because of the low infectious load, DR in Okinawa did not result in excessive deaths from infectious diseases during childhood. It is interesting that infant mortality in the United States in 1915 was higher than that in Okinawa in 1900 [21]. It is likely that low consumption of calories could be dangerous for child health in the conditions of higher mortality from infectious diseases, and not necessarily brings a longevity advantage. For example, we compared American centenarians when they were 30 years old to their shorter-lived peers born in the same calendar year [22]. This study used information on body height and body build available in the 1917 World War I civil draft registration cards. This study showed that the 'stout' body build (being in the heaviest $15 \%$ of control population) was negatively associated with longevity suggesting that detrimental effects of obesity may have an exceptionally long time range. However, slender body build, consistent with low calorie consumption, did not give any longevity advantage compared to medium body build. Thus, severe caloric restriction is not always a necessary condition for living to 100 . In this regard, we would agree with Le Bourg that in contemporary populations DR should be used first for improving the health status of obese people although DR should not be dismissed as a valid approach to extending life span in nonobese individuals.

\section{Acknowledgement}

We would like to acknowledge support from the US National Institute on Aging (NIA grant R01 AG028620).

\section{References}

1 Le Bourg E: Dietary restriction studies in humans: focusing on obesity, forgetting longevity. Gerontology 2012;58:126-128.

-2 Rochon J, Bales CW, Ravussin E, Redman LM, Holloszy JO, Racette SB, Roberts SB, Das SK, Romashkan S, Galan KM, Hadley EC, Kraus WE: Design and conduct of the CALERIE study: comprehensive assessment of the long-term effects of reducing intake of energy. J Gerontol Ser A Biol Sci Med Sci 2011;66:97-108.

3 Rosenbaum MW, Willcox BJ, Willcox DC, Suzuki M: Okinawa: a naturally calorie restricted population; in Everitt AV (ed): Calorie Restriction, Aging and Longevity. New York, Springer Science, 2010, pp 43-53.

4 Japanese Ministry of Health: Abridged life tables. Available at: http://www.Mhlw.Go.Jp/ toukei/saikin/hw/life/tdfk05/dl/data.Pdf. 2010.

5 Willcox DC, Willcox BJ, Todoriki H, Suzuki M: The Okinawan diet: health implications of a low-calorie, nutrient-dense, antioxidant-rich dietary pattern low in glycemic load. J Am Coll Nutr 2009;28:500S-516S.

-6 Jacobsen BK, Oda K, Knutsen SF, Fraser GE: Age at menarche, total mortality and mortality from ischaemic heart disease and stroke: the Adventist health study, 1976-88. Int J Epidemiol 2009;38:245-252.

7 Barker DJP: Mothers, Babies, and Disease in Later Life, ed 2. London, Churchill-Livingstone, 1998.
8 Huxley R, Owen CG, Whincup PH, Cook DG, Rich-Edwards J, Smith GD, Collins R: Is birth weight a risk factor for ischemic heart disease in later life? Am J Clin Nutr 2007;85: 1244-1250.

-9 Rajaleid K, Janszky I, Hallqvist J: Small birth size, adult overweight, and risk of acute myocardial infarction. Epidemiology 2011;22: 138-147.

10 Victora CG, Adair L, Fall C, Hallal PC, Martorell R, Richter L, Sachdev HS: Maternal and child undernutrition 2 - maternal and child undernutrition: consequences for adult health and human capital. Lancet 2008;371: 340-357.

11 Lumey LH, Stein AD, Kahn HS, Romijn JA: Lipid profiles in middle-aged men and women after famine exposure during gestation: the Dutch hunger winter families study. Am J Clin Nutr 2009;89:1737-1743.

-12 Stanner SA, Bulmer K, Andres C, Lantseva OE, Borodina V, Poteen VV, Yudkin JS: Does malnutrition in utero determine diabetes and coronary heart disease in adulthood? Results from the Leningrad siege study, a cross sectional study. Br Med J 1997;315: 1342-1348.

13 Hokama T, Binns C: Trends in the prevalence of low birth weight in Okinawa, Japan: a public health perspective. Acta Paediatr 2009;98: 242-246.
14 Marmot MG, Syme SL: Acculturation and coronary heart-disease in Japanese-Americans. Am J Epidemiol 1976;104:225-247.

15 Fontana L, Klein S, Holloszy JO: Effects of longterm calorie restriction and endurance exercise on glucose tolerance, insulin action, and adipokine production. Age 2010;32:97-108.

-16 Fontana L, Meyer TE, Klein S, Holloszy JO: Long-term calorie restriction is highly effective in reducing the risk for atherosclerosis in humans. Proc Natl Acad Sci USA 2004;101: 6659-6663.

17 Redman LM, Ravussin E: Caloric restriction in humans: Impact on physiological, psychological, and behavioral outcomes. Antioxid Redox Signal 2010;14:275-287.

18 Dirks AJ, Leeuwenburgh C: Caloric restriction in humans: potential pitfalls and health concerns. Mech Ageing Dev 2006;127:1-7.

19 Kristan DM: Chronic calorie restriction increases susceptibility of laboratory mice (Mus musculus) to a primary intestinal parasite infection. Aging Cell 2007;6:817-825.

20 Finch CE, Crimmins EM: Inflammatory exposure and historical changes in human lifespans. Science 2004;305:1736-1739.

21 Centers for Disease Control and Prevention: CDC on infant and maternal mortality in the United States: 1900-99. Population Dev Rev 1999;25:821-826.

22 Gavrilova NS, Gavrilov LA: Search for mechanisms of exceptional human longevity. Rejuvenation Res 2010;13:262-264. 